\title{
24. BIOTURBATION OF SEDIMENTS
}

\author{
David J. W. Piper, Department of Geology, Dalhousie University, Halifax, N. S., Canada \\ and \\ Hans J. Schrader, Geologisch-Palaeontologisch Institut der Universitat Kiel, Kiel, Germany
}

\section{INTRODUCTION}

No systematic study of bioturbation was made on Leg 18. This chapter records data relevant to the study of bioturbation in deep water and the interpretation of ancient bioturbated rocks.

$\mathrm{X}$-radiographs have been prepared from thin slabs of consolidated core. There are no X-radiographs of thin slices of softer sediment. Some visual observations on split cores are also reported.

\section{BURROW MORPHOLOGY}

Table 1 records the abundance of different burrow morphologies visible in X-radiographs and split cores. Burrows from Sites 177 and 178 are generally smaller than those described from Cascadia Channel by Griggs et al. (1969). In muds, subhorizontal burrows predominate.

\section{Zoophycos}

The only taxonomically identifiable burrow was Zoophycos (Plate 1, Fig. 1). This trace fossil has been recently reviewed by Taylor (1967) and Simpson (1970).
Only cross sections of Zoophycos laminae are available in the $5.5 \mathrm{~cm}$ wide cores; no evidence of the overall form has been seen. Alternating thicker and thinner crescentic layers within the laminae, corresponding to Simpson's major and minor lamellae, are visible in some specimens. Only one possible associated tunnel has been found. One surface split parallel to the bedding showed a spiral morphology.

Zoophycos is common in diatom mud of 178-38-1. Laminae are generally 2 to $3 \mathrm{~mm}$ ( $\max .4 \mathrm{~mm}$ ) high. Of seventeen specimens studied, only three preserved the margin. The lamellae within the laminae are of a lighter color (5GY5/1) than the sediment between lamellae and in the over- and underlying part of the core $(5 \mathrm{Y} 3 / 2)$. In place, the lamellae appear to be made up of spherical masses of sediment 0.3 to $1 \mathrm{~mm}$ in diameter. The sediment of the lamellae is much richer in diatoms and other biogenous debris than the surrounding sediment, and many of these skeletons are undamaged. The maximum size of an unbroken diatom from the lamellae is about 600 microns diameter. These unbroken large diatoms concentrated in the lamellae supports Simpson's (1970) contention that the

TABLE 1

Distribution and Abundance of Different Burrows

\begin{tabular}{|c|c|c|c|c|c|c|c|c|c|c|c|}
\hline \multirow[b]{2}{*}{ Core } & \multirow[b]{2}{*}{ Lithology } & \multicolumn{10}{|c|}{ Burrow Type and Abundance } \\
\hline & & A & B & C & D & E & F & G & $\mathrm{H}$ & I & $\mathrm{J}$ \\
\hline $173-18-3^{\mathrm{c}}$ & diatomite & & & & & & & & & & 1 \\
\hline $174-37-4^{c}$ & mud turbidite & 2 & & & & & & & & & \\
\hline $177 \mathrm{~A}-17$ & mud turbidite & & & & 4 & 3 & & & 2 & & \\
\hline $177 \mathrm{~A}-18$ & mud turbidite & & & 2 & 3 & 2 & & & 1 & & \\
\hline $177 \mathrm{~A}-23$ & mud turbidite & & & 3 & 4 & 2 & & & & & \\
\hline $178-38-1$ & mud & 3 & & 2 & 3 & & & & & 2 & \\
\hline $178-44$ & diatom mud & & & & 4 & 2 & & 2 & 2 & & \\
\hline $178-45-1$ & diatom mud & & & 3 & 4 & 3 & & & & 3 & \\
\hline $178-50$ & mud & & & & 3 & 1 & & & 2 & & \\
\hline $178-54$ & claystone and chalk & 4 & 2 & 3 & 5 & 4 & 2 & 3 & 2 & 4 & \\
\hline
\end{tabular}

${ }^{\mathrm{a}}$ Abundances: Scaled 1 (only one example) to 5 (very abundant).

b Burrow types:

A. Zoophycos.

B. c.f. Teichichnus.

C. Vertical burrows less than $1 \mathrm{~mm}$ (Type No. 1 of Griggs et al).

D. Horizontal burrows 1-4 mm (Type No. 2 of Griggs et al).

E. Horizontal burrows 4-10 mm (Type No. 3 of Griggs et al).

F. Horizontal burrows 10-35 mm (Type No. 4 of Griggs et al).

G. Lined burrow, horizontal, $5-20 \mathrm{~mm}$.

H. Vertical short burrows 1-4 mm diameter.

I. Horizontal burrows less than $1 \mathrm{~mm}$.

J. Vertical burrow of diameter more than $10 \mathrm{~mm}$.

${ }^{\mathrm{c}}$ Based only on visual observation of split cores. Others based on X-radiographs of thin slabs. 
lamellae are "only a small part of the volume of sediment moved in driving the tunnel; the bulk of the material was presumably ingested and voided at the surface".

Zoophycos is also abundant in the diatom muds and chalks of parts of 178-54. Laminae here reach up to $6 \mathrm{~mm}$ thick, and although mostly horizontal, some have a gradient of up to 10 degrees. There are also two traces similar to Teichichnus (Plate 1, Fig. 2. - cf. Fig. 7e of Taylor, 1967, who also found rare cf. Teichichnus associated with Zoophycos).

\section{Preservation of Diatom Skeletons in Burrows, Hole 178}

The preservation of diatoms is better in distinct light-colored burrows than in the surrounding sediment, in samples examined from Hole 178 (Core 38, Section 1 and Core 54). Denticula kamtschatika was abundant to common within burrow sediments, and rare in the neighboring sediment. This species was used to trace the grade of preservation. Coscinodiscus marginatus was broken to small pieces both in burrows and surrounding sediment, but showed less dissolution effects within the burrows. Species diversity increased abruptly within the burrow sediments.

Plate 2 shows micrographs of samples from 178-38-1 $(65-67 \mathrm{~cm})$. Figure 1 shows the burrows of type D from which the samples were taken. Figure 2 shows Sample 1, from the surrounding sediment, with strongly damaged Coscinodiscus marginatus fragments. Figures 3 and 4 show Sample 2 - marginal debris with much clay. Figure 5 shows Sample 3, from the center of the burrow, with fine silicified diatom tests, including Denticula kamtschatika and pieces of Coscinodiscus marginatus and Coscinodiscus sp.

\section{BIOTURBATION OF TURBIDITES}

Special attention was paid to bioturbation in turbidites because of its significance in the study of the finer parts of turbidites.
Observations on split cores showed that penetrative disruption of sand and coarse silt beds varied from zero to complete disruption in different parts of the various holes. No generalizations were recognized. Thicker beds are only exceptionally penetrated. Their upper parts may show bioturbation, but this is difficult to recognize without $\mathrm{X}$-radiographs. However, X-radiographs, and the lack of penetrative disruption of thin silt laminae, show that the muddy tops of some turbidites have suffered virtually no bioturbation.

A series of graded silt-mud turbidites from Hole 175, showing varying amounts of bioturbation were analyzed for grain size distribution (Figures 1).

Beds described on the ship as having very little or no mottling $(E, F$, and $G$ ) have almost no sand in the mud. Strongly mottled beds $(C)$ have over 20 percent sand in the mud; with moderate mottling $(A) 10$ to 20 percent; and with slight mottling $(B, D), 3$ to 10 percent. In some cases (notably $A$ ) there is a progressive increase in silt and sand content going downwards through a bed. This was also found by Piper and Marshall (1969). The amount of mottling reflects the intensity of bioturbation, which mixes sand and silt from low in a graded bed with the silt and clay higher up.

\section{REFERENCES}

Griggs, G. B., Carey, A. G. and Kulm, L. D., 1969. Deep-sea sedimentation and sediment fauna interaction in Cascadia Channel and on Cascadia Abyssal Plain. Deep-Sea Res. 16, 157.

Piper, D. J. W. and Marshall, N. F., 1969. Bioturbation of Holocene sediments on La Jolla deep sea fan, California. J. Sediment. Petrol. 39, 601.

Simpson, S., 1970. Notes on Zoophycos and Spirophyton. In Trace Fossils. Crimes, T. P. and Harper J. C. (Eds.). Liverpool. 505.

Taylor, B. J., 1967. Trace fossils from the Fossil Bluff Series of Alexander Island. Brit. Antarct. Surv. Bull. 131. 

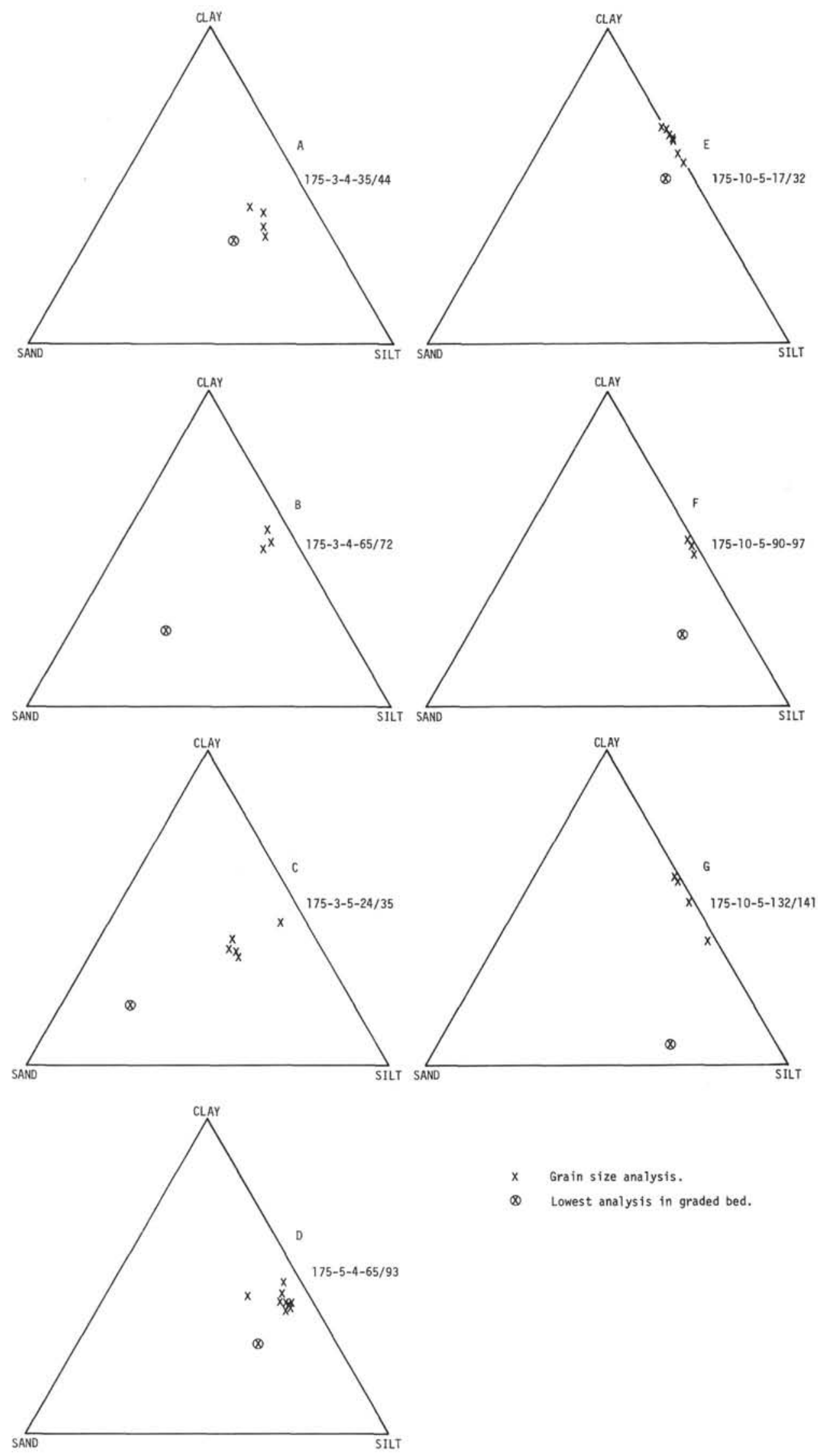

$x \quad$ Grain size analysis.

$\otimes \quad$ Lowest analysis in graded bed.

Figure 1. Grain size analysis of bioturbated graded silt-mud turbidites from Site 175. Amount of sand in the muds is proportional to the intensity of mottling (bioturbation). 


\section{PLATE 1}

Bioturbation in Core 54, Site 178.

Figure 1

Figure 2

Figure 3

Figure 4
Zoophycos, in mudstone. 178-54-1(124-129 cm).

Trace fossil, c.f. Teichichnus in mudstone. $178-54-1(105-111 \mathrm{~cm})$

Trace fossils in nanno-bearing claystone. Shows the predominantly subhorizontal orientation of larger burrows. $178-54-2\left(1-12 \frac{1}{2} \mathrm{~cm}\right)$

Trace fossils in chalk. Shows unusual vertical burrow cut by Zoophycos. 178-54-5. 
PLATE 1
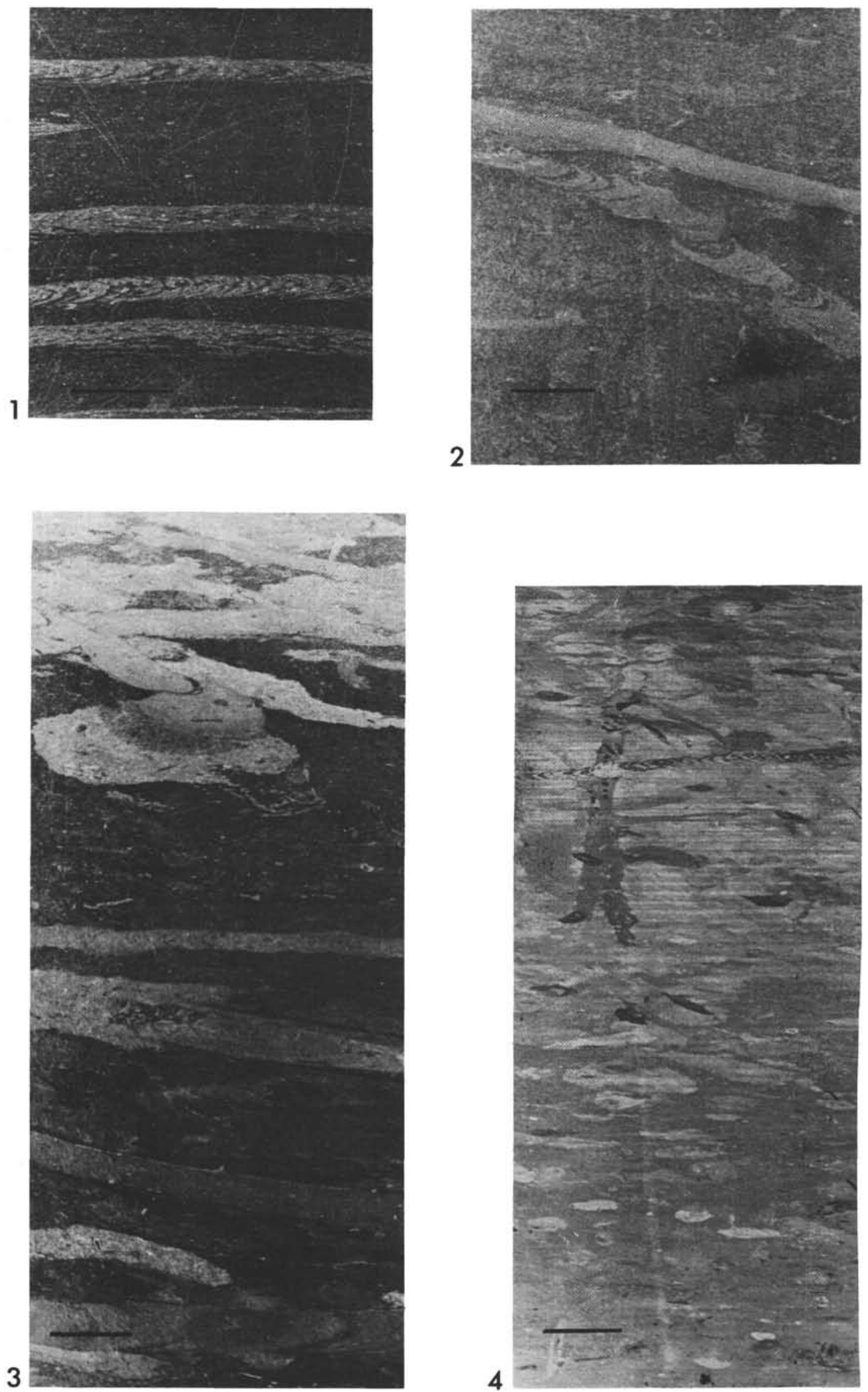


\section{PLATE 2}

Preservation of siliceous skeletons in burrows at Site 178.

Figure 1 Two burrows in 178-38-1(65-67 cm), showing position of samples shown in Figures 2-5. Burrow is of type D (see Table 1) and is in diatom silty clay.

Figure 2 Sample 1, from sediment surrounding the burrow, with strongly damaged Coscinodiscus marginatus fragments.

Figures 3-4 Sample 2, from margin of burrow, with much clay.

Figure 5 Sample 3, from center of burrow, showing fine siliceous diatom tests. 
PLATE 2

Site $178-38-1-65 / 67 \mathrm{~cm}$
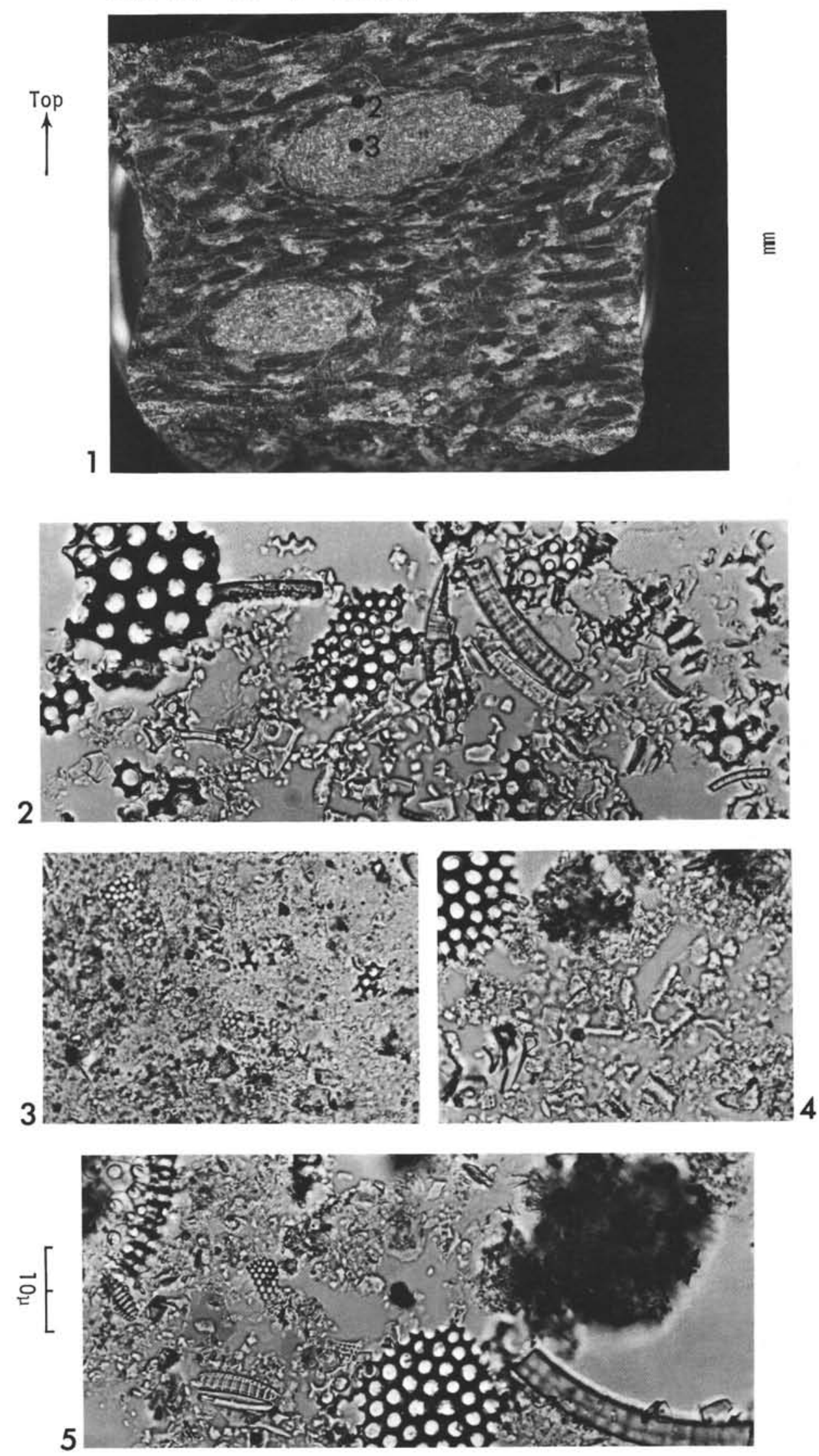